\title{
ПРОБЛЕМА СОЦІАЛЬНО-ІСТОРИЧНОГО СУБ'ЄКТА В СУЧАСНІЙ СОЦІАЛЬНІЙ ФІЛОСОФІї
}

\section{Т.В. Кушерець}

Проблема рушійних сил соціальних процесів, відповідальності за історію та долю людини завжди була однією з головних тем в соціальній філософії. В різні епохи філософська думка намагалася піднятися до загальних принципів, виходячи 3 яких можна було б визначити історичний шлях людства. В своєму пошуці вона з необхідністю ставила питання про суб'єкт історії- ту силу, яка визначає історичний поступ та відповідальна за нього. Впродовж тривалого розвитку філософської думки суб'єкт історії був секуляризованим, гуманізованим та соціалізованим.

Спочатку він був винесеним за межі людського та соціального світу в область надприродного і поставав у вигляді божественних сил, що діють ззовні, формуючи та контролюючи індивідуальне та соціальне життя, людські біографії та поступ історії. Пізніше людське суспільство, його функціонування та зміни розглядалися як такі, що визначаються природними силами - фізичними, біологічними, кліматичними, географічними. У такий спосіб суб'єкт історії був секуляризованим, він знаходився поза суспільством і людьми. Починаючи з філософії Відродження енергію суб'єкта почали приписувати людським істотам державним діячам, героям, пророкам і геніям. Їх здатність бути рушіями суспільного життя пов'язувалася з харизмою, яка була вродженою або мала божественне походження та індивідуально розвивалась, але не була соціально визначеною.

На початку XIX століття мислителі стали звертатися до пробле-

Актуальні проблеми духовності 
ми обумовленості дій суб'єкта соціальним середовищем. Соціалізації суб'єкта сприяло виникнення соціології, яка робила акцент на суспільстві як на тотальності, що саморегулюється та самотрансформується, та матеріалістичне розуміння історії К. Маркса. Суб'єкт історії розглядався як сила соціального організму, що проявляється в соціальному житті у незворотному напрямку. Саме у цей час виникла небезпека вилучення індивіда, людини з соціальних процесів, які мали цілком об'єктивний характер. Проте ці концепції не виходять за межі світобачення, що склалося під впливом раціоналістичної філософії Нового часу та Просвітництва, тобто віри в те, що людство може і повинне шляхом розвитку наукової і раціональної думки вдосконалювати та поліпшувати своє суспільне життя. Люди визнаються спочатку як суб'єкти пізнання, а вже потім - дії. Концепції дегуманізованого суб'єкта швидко виявили свою обмеженість, оскільки суспільні колізії, що мали місце в реальному житті, спростовували думку про те, що історія здійснюється десь поза спинами людей. Соціалізований суб'єкт повинен був гуманізуватися.

Гуманізація суб'єкта здійснювалась кількома шляхами.

По-перше, соціальними характеристиками стали наділятись «Великі особистості», виняткова роль та влада яких в історії стали розглядатися як результат містичної еманації творчої енергї суспільства, а не як вроджені якості. У них вбачали зосередження, втілення структурних напружень, соціальних настроїв, історичних традицій. Їх вчинки приймали форму «репрезентативної активності», що здійснюються в інтересах людей для того, щоб зробити їх у майбутньому щасливими.

По-друге, ідея суб'єкта екстраполювалась на всіх людей, а не лише на «великих», на всі ролі, а не лише на керівні. Класова теорія K. Маркса була першою серед таких концепцій, тому і мала риси перехідної (пролетаріат вже колективний суб'єкт, але здійснює свою історичну місію в ім'я блага всіх людей). З'являється усвідомлення того, що хоча кожному індивідові належить лише маленька роль в ансамблі соціальних змін, останні виявляються сукупним результатом діяльності всіх членів суспільства. Економічна теорія дала «метафору ринку» і допомогла проаналізувати, як із численних та розпорошених рішень численних виробників і споживачів, продавців та покупців виникає «невидима рука», що породжує зміни на макрорівні. Поняття ненавмисних, прихованих наслідків людських дій стає вирішальним, оскільки соціальні зміни розглядаються як сукупний, історично акумульований результат того, що здійснюють всі члени суспільства, переслідуючи свої егоїстичні цілі. 
Одначе вищезгадане уявлення про рушійні сили історії та суб'єктів змін не можна, наш погляд, вважати вичерпним. У реальному житті спостерігається однотипність дій і рішень, якому слід дати пояснення. Образ спонтанних, ненавмисних змін виключає можливість аналізу свідомої планованої діяльності людей, спрямованої на соціальні трансформації. Без раціонального компонента саме поняття суб'єкта втрачає смисл. Крім того, люди не діють ізольовано, вони взаємодіють в рамках певних груп та спільнот. Тому уявлення про суб'єкт повинні бути доповнені поняттям про колективні та корпоративні дії. Одні люди в суспільстві виконують ролі керівників, працюючи в урядових, законодавчих та адміністративних органах, проводять зміни «згори». Інші ініціюють трансформації «знизу» - це асоціації, групи тиску, соціальні рухи. «Їх комплексна взаємодія утворює політичну арену сучасних суспільств, і цілеспрямований результат їх дій переплітається з розпорошеною повсякденною активністю індивідуальних діячів. Так індивіди і колективи спільно формують непрямий курс людської істоpiï» $[8$, c. 244].

$\mathrm{y}$ вітчизняній філософській та соціологічній думці утвердилась ідея про діалектичний зв'язок між суспільством та людьми, що спиралась на марксистську традицію. Однак їі активних прихильників можна знайти і серед західних мислителів, що будують свої теорії на інших методологічних засадах. Так, П. Бергер та Т. Лукман у своїй відомій праці «Соціальне конструювання дійсності» стверджують, що суспільство формує індивідів, котрі у свою чергу творять суспільство, і це перебуває в безперервному діалектичному процесі. Як зазначають прихильники цієї моделі, «соціальну структуру не можна охарактеризувати як деяку самостійну річ, окрему від людської діяльності, що створила їі». Але так само, одного разу будучи створеною, ця «структура сприймається індивідом як чужа фактичність та примусова інструментальність». «Вона десь там, глуха до його бажань ..., інша, ніж він сам, та опирається йому» [2, с.216]. Ця схема здатна віддати належне як суб'єктивним і навмисним граням суспільного життя, так і зовнішній примусовій силі соціальних фактів, і тим самим зразу уникнути волюнтаристських висновків веберівської традиції та всякої верифікації, пов'язаної з дюркгейміанством.

Так, погоджуючись з Дюркгеймом, що система знаків, котру ми використовуємо для висловлювання своїх думок, грошова система для сплати податків, практичні процедури, що використовуються в професійній діяльності, функціонують незалежно від нашого використання їх, прихильники цієї моделі трактують такі системи та практи- 
чні процедури як об'єктивації, що за певних умов допускають відчужену форму. Об'єктивацією вони називають процес, в рамках якого людська суб'єктивність втілюється в продукти, які доступні самому суб'єкту та його оточенню як елементи деякого спільного світу, а відчуження - як процес котрий розриває єдність творіння, виробництва та його результату, продукту. Наприклад, мови, форми політичної та економічної організації, культурні норми - все це, в кінцевому підсумку, втілення людської суб'єктивності, а суспільство постає як об'єктивація людських істот. Останні, зі свого боку, повторно привласнюють або інтерналізують у своїй свідомості суспільство.

На думку сучасного західного філософа Р.Бхаскара, така модель має ряд недоліків, бо, з одного боку, вона заохочує волюнтаристський ідеалізм у розумінні соціальної структури, а з іншої,- - механістичний детермінізм у розумінні людей. В прагненні подолати помилки обох стереотипів вона лише здатна на їх комбінування. «Люди і суспільство, - стверджує Бхаскар, - не пов'язані «діалектично». Вони не утворюють двох моментів одного і того ж процесу. Скоріше вони відносяться до зовсім різних областей явищ [3, с. 227]. Мислитель зауважує, що можна вважати істиною, що суспільство не могло б існувати без людської діяльності, тому реіфікація - помилка. Вірно також, що така діяльність не відбувалася б, якби включені в неї індивіди не мали б розуміння того, що вони роблять. «Але вже не вірно говорити, що суб'єкти творять суспільство. Скоріше, треба було б сказати: вони відтворюють або перетворюють його» [3, с. 227]. Іншими словами, якщо суспільство завжди постає уже створеним, готовим, тоді будьяка конкретна людська практика може тільки видозмінювати його. Сукупність таких актів підтримує життя суспільства або змінюе його.

У контексті вищеокресленої теорії об'єктивація набуває іншого значення. Вона, як свідома людська діяльність, здійснюється вже на наявних об'єктах, і її не можна уявити як таку, що протікає за їх відсутності. Будь-яка діяльність передбачає первинне існування соціальних форм. Суспільство $є$ «матеріальною причиною» в Арістотелівському розумінні, повсюдною умовою людської діяльності та її безперервно відтворюваним результатом.

Властивості соціальних форм можуть дуже відрізнятися від властивостей індивідів, від діяльності котрих вони залежать. Так, цілеспрямованість, інтенціональність, усвідомленість характеризують людські дії, а не зміни в соціальній структурі. Люди в своїй свідомій діяльності найчастіше неусвідомлено відтворюють структури, що спрямовують їх самостійні «виробництва». Так, люди вступають у шлюб 
не для того, щоб відтворити нуклеарну сім'ю, і працюють не для того, щоб підтримувати життя капіталістичного господарства. Одначе і сім'я, і господарство виявляються ненавмисним наслідком, невідворотним результатом і одночасно необхідною умовою їх діяльності. Залучення до соціальної діяльності - це, сама по собі, свідома людська дія, яку можна описати або виходячи із розумних міркувань суб'єкта на користь участі в ній, або в категоріях його соціальної функції або ролі.

Подану вище модель зв'язку «суспільство/особистість» можна підсумувати так: люди не створюють суспільство, бо воно завжди передує їм і становить необхідну умову для їх діяльності. На суспільство потрібно дивитись як на сукупність структур, звичних практичних процедур та умовностей, корті індивіди відтворюють і перетворюють, але котрі б реально не існували, якби вони цього не робили. Це відтворення та перетворення суспільства хоча у більшості випадків здійснюється несвідомо, однак є ще і деяким досягненням, результатом вмілого виконання активними суб'єктами, а не механічним наслідком попередніх умов. Процесам, завдяки яким формуються та підтримуються накопичені вміння, навички, майстерність, що властиві певним соціальним контекстам і необхідні для відтворення і перетворення суспільства, можна дати родову назву «соціалізація».

Оскільки соціальні структури існують тільки завдяки видам діяльності, які ними скеровуються, вони не можуть існувати незалежно від ідей, які є у суб'єктів відносно того, що вони роблять, тобто від якихось теорій цих видів діяльності. Оскільки такі теорії також виявляються об'єктами можливих перетворень і тому можуть бути відносно стійкими і автономними. «Те, що утворює суть будь-якої форми суспільного союзу або суспільного відношення - будь то форма правління як-то монархія, республіка, або форма відношення між класами як рабство, кріпосне право, або вільнонаймана праця, або особистісні відношення як сім'я, союз дружби і т. п. - із чого складається буття цієї суспільної форми, є об'єктивна ідея, породжена самою людиною і пануюча над нею через акт віри в неї та служіння їй. Людина є завжди не самодержавний творець і деміург свого буття, а суспільне буття є завжди більше, ніж іманентне вираження суто людських пристрастей та суб'єктивних поривів; людина на всіх стадіях свого буття є неначе медіум, провідник вищих начал і цінностей, котрим вона служить і котрі вона втілює,- правда, медіум не пасивний, а активний у творчому здійсненні цих начал» [6, с. 75].

Слова про те, що «в таку-то епоху править такий-то чоловік, такий- 
то народ, чи група народів» рівносильні словам: в таку-то епоху панує така-то система думок, ідей, смаків, прагнень, цілей». Тому людина спроможна їх лише усвідомити, виразити, уособити в собі, через свою діяльність здійснити. Історична творчість полягає у відчутті голосу епохи. I можливо мав рацію Ортега-і-Гассет, коли говорив, що не всі однаково його відчувають. «Необхідно, щоб хоч якийсь дух мав владу і користувався нею, поставляючи потрібними думками тих, хто таких не має, тобто більшість людей. Без таких думок суспільство перетворилося б в хаос, навіть гірше - в історичне ніщо. Життя б втратило всяку структуру, організацію» [5, с. 128].

Люди не створюють суспільство. Люди - його суб'єкти. Адже суб'єкт - це той, хто користується певними засобами для того, щоб щось зробити. «Суб'єкт відчуває своєрідну пристрасть трансцендентального характеру до всього, що його оточує, до об'єктів, що є у його розпорядженні, а також до інших людей, з якими він вступає у стосунки, і в кінці кінців до самого себе» [7, с. 289].

Реальна суб'єктивність вимагає умов, ресурсів і засобів для творчої активності суб'єкта. Такі матеріальні причини можна вважати результатом попередніх об'єктивацій, але у будь-якій діяльності вони аналітично і фактично необхідні. Попередній компонент в соціальній дії ніколи не може бути зведеним до нуля і проаналізованим до кінця. Саме тому радикальні революції, котрі ставлять за мету знищити в суспільстві все його минуле і побудувати майбутнє на основі нехай щонайкращого плану приречені на невдачу, а суспільний організм через деякий час знову оживає під дією здорових сил минулого, що в ньому збереглися.

Таким чином, суспільство забезпечує необхідні умови для цілеспрямованої людської дії, а цілеспрямована людська дія завжди виражає і використовує ту чи іншу соціальну форму. Однак ні суспільство, ні дії не можна ототожнювати, зводити одне до одного, пояснювати одне 3 одного. Існує онтологічний розрив між суспільством і людьми і особливий спосіб зв'язку - відтворення/перетворення.

Запропонована модель відношення «людина-суспільство» не заперечує індивідуалістську істину, що люди - єдині рушійні сили в історії (у тому розумінні, що нічого не проходить, так би мовити, за їх спинами, тобто, що все, що відбувається проходить у сфері їх діяльності і завдяки їм). Більше того, соціальні структури потрібно розуміти як такі, що в принципі дозволяють, забезпечують засоби та можливості діяти, а не просто як примусові утворення. В рамках цієї моделі суспільство слід розуміти як таке, що «дозволяє людям свідомо пе- 
ретворювати соціальні умови свого існування (соціальну структуру) так, щоб максимізувати можливості для розквіту і невимушеного прояву своїх природних (родових) здібностей» [3, с. 230].

Модель суспільства, що постійно відтворюється / перетворюється дає чіткий критерій історично суттєвих подій, а саме таких, котрі ініціюють, або викликають розломи, «мутації, або більш узагальнено, перетворення у соціальних формах (наприклад Французька революція). Такі суспільні трансформації можуть призводити до утворення історичних індивідів нового типу. Як переконливо довела Х. Арендт, на початку XX століття «падіння охоронних стін між класами перетворило сонні більшості, що стоять за всіма партіями, в одну величезну, неорганізовану, безструктурну масу озлоблених індивідів» [1, с. 419]. Саме чисельність цієї маси всім незадоволених і зневірених людей різко зросла в Німеччині після першої світової війни і спричинила встановлення жорстокого нацистського режиму.

З урахуванням сказаного вище, потрібно розглядати проблему співвідношення стихійного і свідомого у суспільному житті. Можна виділити два основних типи соціальних порядків: «свідомі» та «спонтанні» (Хайек). «Свідомі» порядки створюються цілеспрямованою діяльністю, розумом людини і функціонують за попередньо розробленим планом, вони спрямовані на досягнення ясно визначених цілей і будуються на основі конкретних наказів. Спонтанні порядки складаються в ході органічного еволюційного процесу, вони не втілюють чийогось задуму і не контролюються з єдиного центру. Координація в них досягається не за рахунок підкорення деякій загальній меті, а за рахунок використання універсальних правил поведінки. Так, до свідомо керованих систем відносяться армії, державні установи, промислові корпорації. До структур, які самі організовуються і регулюються, належать мова, право, мораль, ринок. Останні, за відомим висловом А. Фергюсона, можна назвати продуктом людської дії, а не розуму. Складне сплетіння багатьох таких порядків утворило сучасне суспільство. У пошуках адекватного терміну, який би відобразив його унікальний характер можна звернутися до поняття «великого суспільства» (А. Сміт), «відкритого суспільства» (К. Поппер), «розширеного порядку людської співпраці» (Хайек).

Оскільки соціальні структури самі є соціальними продуктами, вони можуть ставати об'єктами перетворень, а тому можуть бути тільки відносно стійкими. На додачу диференціація та розвиток видів соціальної діяльності (як при «розподілі праці» та при «розширеному відтворенні») обумовлюють їх взаємозалежність; тому соціальні стру- 
ктури можуть бути тільки відносно автономними. Суспільство можна уявити у вигляді членороздільного «ансамблю» таких відносно незалежних і стійких структур, тобто як складну повноту-тотальність, здатну змінюватися і в своїх складових, і у їх взаємовідношеннях.

Сучасне соціальне мислення постійно супроводжується рефлексією про те, з якої перспективи пропонується розуміння і пояснення світу. В сучасній соціальній філософії та соціології утвердилось відносно нове розуміння природи соціальної реальності. Відносно нове тому, що сконструйована в минулому і досі прийнята як легітимна традиція класичних вчень не дозволяє сумніватися у власній життєвості та тривалій актуальності. В цьому новому розумінні можна виділити два моменти.

По перше, поділ на суб'єкти та об'єкти реальності не встановлений наперед, апріорі. Він не більше ніж сторонній і зовсім не обов'язковий продукт аналітичних зусиль теоретиків, доцільність якого тепер потрібно довести. Вичерпав себе пізнавальний потенціал диференціації реальності на суб'єктивну та об'єктивну, на внутрішню і зовнішню, або, щонайменше, переконаність в релевантності такого поділу дуже похитнулася. В соціальній реальності виділяють два рівні: рівень індивідуальностей та рівень спільнот. Перший представляють окремі люди або члени конкретних колективів (груп, асоціацій, спільностей, рухів і т. п.), другий - абстрактні соціальні цілісності надіндивідуального типу, що представляють своєрідну, специфічну соціальну реальність (суспільства, культури, цивілізації, суспільно-економічні формації, соціальні системи і т. п.). Соціальні цілісності інтерпретуються не як прості сукупності або метафізичні сутності, а як структури; соціальні індивіди також розглядаються не як пасивні об'єкти, або повністю автономні суб'єкти, а як діячі, що обмежені у своїй діяльності.

Спроби інтеграції цих двох рівнів розпочалися ще в першій половині XX століття, бо саме в поєднанні функціонування структур та діях суб'єктів прихована загадка соціального становлення. Структурний функціоналізм Т. Парсонса був найбільш вражаючою спробою в даному аспекті.

Порівняно недавно теоретичні реконструкції Е. Гіденса привели до формулювання теорії структурації, в котрій англійський мислитель делегітимізує опозицію структури (статичного, синхронного) і дії (динамічного, асинхронного) і наполягає на дуальності структури. Свої погляди британський мислитель розвиває в полеміці з функціоналістами, завдяки яким в наукових колах поширилося уявлення про структуру як про деякий устрій соціальних відносин: дещо подібне до основних 
конструкцій будови або скелета живого організму. Більше того, вони продовжили традицію Е. Дюркгейма в ототожненні «структур» 3 «примусом». В наміри Гіденса не входило «відмовитися від концепта, котрий без сумніву корисний і необхідний для того, щоб представляти соціальні відносини між індивідами та спільностями як оформлені та впорядковані, що і означає їх відтворюваність у просторі». Він не пропонує застосовувати термін «структура» для вказівки на подібну оформленість та впорядкованість, а також утримується від пов'язування структури з примусом, бо вважає, що саме останнє породжує дуалізм між теорією дії та інституціональною теорією. «Якщо структуру розуміти як те, що являється зовнішнім по відношенню до дій індивідів, то природно вважати $\dddot{1}$ автономною формою, незалежною від подібних дій; або, гірше того, такою, що повністю обумовлює ці дії через соціальні причини» $[4$, с. 78$]$.

Для того, щоб зробити поняття структури придатним для цілей сучасного соціального аналізу британський мислитель аналізує зміст ще одного популярного поняття - система. Більшість прихильників як функціоналізму так і інших напрямків вживають обидва терміни і вважають, що соціальні системи мають структури. Структура - це морфологія, «стійке поєднання частин». Якщо ж мається на увазі функціонування, тоді мова йде про систему. Система - це «функціонуюча структура». «Можливо це і справедливо для біологічних організмів, але до суспільства навряд чи можна таке застосувати ... Суспільство, що перестало функціонувати - тобто таке, що не відтворює себе у просторі та часі, - просто перестає існувати, зникає. I тому немає нічого дивного в тому, що відмінність між структурою і системою стає все менш помітною, а обидва поняття вживаються як синоніми» [4, с. 79]. Соціальні системи (і навіть суспільства, як вищий тип соціальних систем) представляють собою відтворювані відносини між індивідами та (або) спільнотами. Якщо розуміти систему саме так, тоді поняття структура звільняється для інших завдань.

Гіденс вважає, що поняття структури повинне застосовуватися в сучасному соціальному аналізі у тому значенні, котре зовні нагадує концепцію Соссюра про структурні властивості мови. «Структура вказує на правила і ресурси, що наявні в соціальних системах, але мають лише «віртуальне існування». Під «правилами» слід розуміти соціальні конвенції, а їх знання передбачає і знання контекстів їх застосування. Ресурсами я називаю «здатності до опредмечування та уречевлення», що обумовлюють певний порядок подій ... Поняття ресурсів доцільно застосовувати при структурному вивченні домінування 
та аналізу відношень влади в соціальних системах. Концептуалізувати структуру як правила та ресурси (або структуру як сітку правила/ресурси) значить трактувати ї̈ як можливість та як примус. Одне, власне кажучи, не виключає іншого. За ілюстрацією і поясненням знову доречно звернутися до мови. Будь-яка мова має жорсткі обмеження, що стримують мислення, але в той же час залишають простір і дозволяють широку варіативність оперування поняттями, без чого мова немислима і неможлива» $[4$, с. 80$]$.

Звертаючись до лінгвістичних прикладів, британський мислитель не вважає, що суспільство $є$ аналогічним мові, або може вивчатися так, як мова - це типова помилка структуралістів. Аналогія з мовою потребує м'якої та обережної трактовки, без якої важко пояснити що таке «дуальність структури». Коли формулюється речення, людина звертається до різноманітних синтаксичних правил певної мови. Але використання правил сприяе їх відтворенню як структурних властивостей певної мови в якості рекурсивно залучених в лінгвістичну практику певної спільноти. Момент виробництва мовного акту у той же час сприяє відтворенню структурних якостей, котрі роблять можливим саме мовлення. «Важливо прийняти до уваги, що «відтворення» тут не означає повторення одного і того ж: потенціал змін ніби вбудований в механізм соціального відтворення» $[4$, с. 81$]$.

Гіденс запропонував замінити статичне поняття структура в динамічну категорію «структурація» для опису колективної поведінки людей. «Наше життя проходить в трансформації», а її основним змістом $\epsilon$ постійне виробництво і відтворення суспільства. Отже, «вивчати структурування соціальної системи означає вивчати ті шляхи, котрими ця система - в рамках застосування загальних правил і ресурсів і в контексті непередбачуваних результатів - твориться і відтворюється у взаємодії. «Структурні властивості систем є одночасно і засобом, і результатом практики, в процесі якої формуються дані системи» $[8$, c. 249]. Це теорема «подвійної, або дуальної структури».

Остаточним рушієм «структурування» $є$ люди - діячі (або агенти), множина індивідів у їх повсякденній поведінці. При цьому всі соціальні діячі знають дуже багато про умови та наслідки того, що вони роблять у своєму повсякденному житті. Деякі умови визнаються неусвідомленими, а деякі наслідки - ненавмисними. 3 цього можна зробити висновок, що якщо навіть розглядати історію як безперервний продукт діяльності, як створену із подій, рушієм яких є індивід, то це зовсім не означає, що продукт співпадає з намірами. Людська історія створюється цілеспрямованою діяльністю, але вона не $є$ свідомо запланованим 
проектом, вона постійно зриває спроби свідомо вести її у певному напрямку.

У розумінні сучасних мислителів структура дуальна, оскільки вона і ніби знаходиться поза індивідами, і ніби в них самих. Цю незворотню занесеність структури у внутрішній світ індивідів і в колективні почуття та уявлення репрезентують такі поняття як «актор»або «агент»діючі у соціумі одиниці. Актором є саме той діяч, що невимушено рухається в диференційованому та стратифікованому просторі. Невимушеність руху забезпечується, згідно П. Бурд'є, «габітусом»-сукупністю інтерналізованих зразків поведінки, котрі у безпосередньому життєвому процесі обумовлюють індивідуальну та групову соціальну компетентність, тобто здатність і навички правильно розуміти, адекватно оцінювати те, що відбувається, та ефективно діяти на основі такого розуміння та винесених оцінок, здатність приборкувати стихію соціальності, легко розпізнавати стабільне та минуче в різноманітному потоці дійсності.

Реальність виявляється тоді не набором надособових і анонімних структур, а сукупністю різнорідних практик. Останнє і $є$ реальність, тобто діючі, а значить рухомі, структури.

\section{1 Бібліографія}

[1] Арендт X. Джерела тоталітаризму. - К.: Дух і літера, 2002.

[2] Бергер П., Лукман Т. Социальное конструирование действительности. - М., 1995.

[3] Бхаскар Р. Общества. // Социо-логос. Социология. Антропология. Метафизика.-М., 1991.

[4] Гіденс Е. Структура як правила та ресурси. // Людина і суспільство. - К., 1999.

[5] Opтега-и-Гассет X. Восстание масс. // Вопросы философии.1989. 一№ 3-4.

[6] Франк С.Л. Духовные основы общества. - М. 1992.

[7] Фуко М. Герменевтика субъекта. // Социо-логос. Социология. Антропология. Метафизика.-М., 1991.

[8] IIтомпка П. Социология социальных изменений. - М., 1999. 